\title{
EXPANDING NUCLEAR ARMS CONTROL: DOD IMPERATIVES IN THE AFTERMATH OF
}

11 SEPTEMBER 2001

by

Lieutenant Colonel Carlton B. Reid, Jr.

United States Army

Colonel William C. Vogt

Project Advisor

The views expressed in this academic research paper are those of the author and do not necessarily reflect the official policy or position of the U.S. Government, the Department of Defense, or any of its agencies.

U.S. Army War College CARLISLE BARRACKS, PENNSYLVANIA 17013 


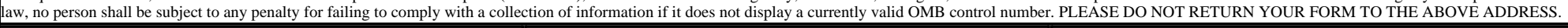
1. REPORT DATE (DD-MM-YYYY) 07-04-2003

4. TITLE AND SUBTITLE

Expanding Nuclear Arms Control

DOD Imperatives in the Aftermath of 11 September 2001

Unclassified

6. AUTHOR(S)

Reid, Carlton B. ; Author

7. PERFORMING ORGANIZATION NAME AND ADDRESS

U.S. Army War College

Carlisle Barracks

Carlisle, PA17013-5050

9. SPONSORING/MONITORING AGENCY NAME AND ADDRESS

12. DISTRIBUTION/AVAILABILITY STATEMENT

APUBLIC RELEASE

13. SUPPLEMENTARY NOTES

14. ABSTRACT

See attached file.

15. SUBJECT TERMS

16. SECURITY CLASSIFICATION OF:
a. REPORT
b. ABSTRACT
c. THIS PAGE
Unclassified
Unclassified Unclassified

17. LIMITATION
OF ABSTRACT
Same as Report
(SAR)

\begin{tabular}{|l|l|}
18. & 19. \\
NUMBER & RI \\
OF PAGES & R \\
42 & \\
& 190
\end{tabular}

3. DATES COVERED (FROM - TO)

xx-xx-2002 to $x x-x x-2003$

5a. CONTRACT NUMBER

5b. GRANT NUMBER

5c. PROGRAM ELEMENT NUMBER

5d. PROJECT NUMBER

5e. TASK NUMBER

5f. WORK UNIT NUMBER

8. PERFORMING ORGANIZATION REPORT

NUMBER

10. SPONSOR/MONITOR'S ACRONYM(S)

11. SPONSOR/MONITOR'S REPORT

$\operatorname{NUMBER}(S)$
19. NAME OF RESPONSIBLE PERSON

Rife, Dave

RifeD@awc.carlisle.army.mil

19b. TELEPHONE NUMBER

International Area Code

Area Code Telephone Number

DSN 


\section{ABSTRACT}

AUTHOR: $\quad$ Carlton B. Reid, Jr.

TITLE: $\quad$ EXPANDING NUCLEAR ARMS CONTROL: DOD IMPERATIVES IN THE AFTERMATH OF 11 SEPTEMBER 2001

FORMAT: Strategy Research Project

DATE: $\quad 07$ April $2003 \quad$ PAGES: 42 CLASSIFICATION: Unclassified

Weapons of mass destruction pose an enormous threat to security and stability in the world as articulated in the Bush administration's recently published National Security Strategy. They constitute the greatest threat in the hands of terrorist groups and rogue states, sources which nonproliferation policies are designed to counter. However, weapons of mass destruction materials are also a threat from rational, non-rogue states including traditional world powers and states seeking prestige through the acquisition of weapons of mass destruction. Unless reduced and controlled, these materials may find their way into the hands of those willing to use them. To counter weapons of mass destruction proliferation and strengthen relations with allies and partners, the United States must engage the international community, adopt the Nuclear Threat Initiative, and charge the Department of Defense to provide trained and ready forces of the Defense Threat Reduction Agency's On-Site Inspection Directorate to implement adversarial, reciprocal and cooperative nuclear inspection regimes. 
ABSTRACT

EXPANDING NUCLEAR ARMS CONTROL

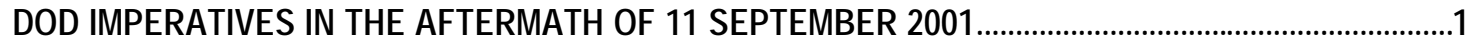

THREAT ENVIRONMENT FOR WEAPONS OF MASS DESTRUCTION......................... 2

RUSSIA AND THE FORMER SOVIET UNION .................................................

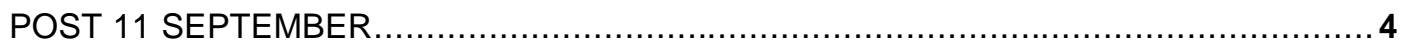

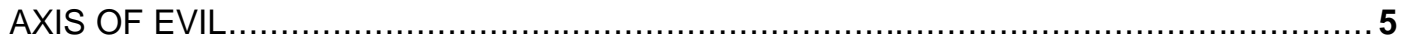

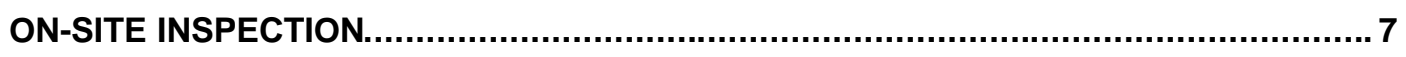

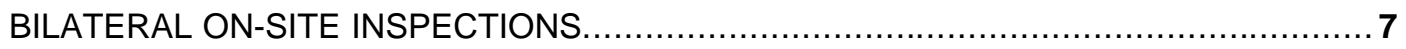

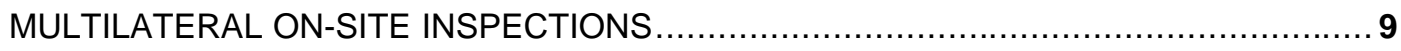

INTERNATIONAL ATOMIC ENERGY AGENCY STRENGTHS AND WEAKNESSES..... 10

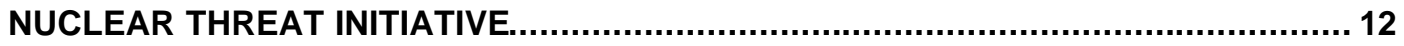

MEETING THE NUCLEAR CHALLENGE........................................................... 19

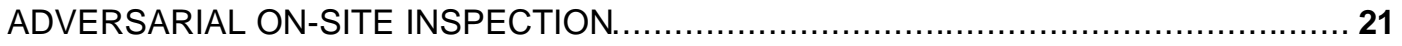

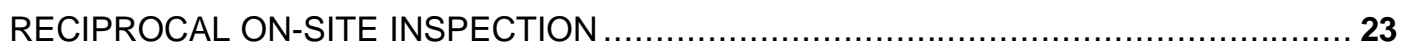

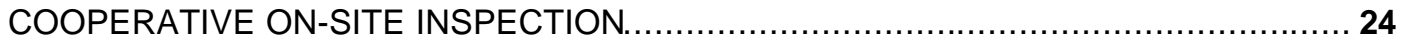

THE NUCLEAR AND COOPERATIVE THREAT REDUCTION BRANCH.......................27

ENDNOTES

BIBLIOGRAPHY 


\section{EXPANDING NUCLEAR ARMS CONTROL DOD IMPERATIVES IN THE AFTERMATH OF 11 SEPTEMBER 2001}

Senior civilian and military leaders of the Department of Defense routinely make difficult choices in the application of resources appropriated by Congress. Of necessity, military leaders structure forces to accomplish national security tasks across a wide spectrum of conflict in concert with other executive departments, Congress, and international bodies such as the United Nations and the North Atlantic Treaty Organization. But first, each activity must survive the Department of Defense's force management process. The On-Site Inspection Directorate of the Defense Threat Reduction Agency, once the darling of the Reagan-Bush administrations, now confronts the same scrutiny imposed on other agencies and services, as decision makers trade spaces and programs to transform the Department of Defense.

Fortunately, the Secretary of Defense's emphasis on capabilities force management provides the framework within which to develop concepts and missions and structure forces to implement arms control. Recent events, as well as President George W. Bush's Report on the National Security Strategy, point to weapons of mass destruction as the major threat to U.S. national security, especially if they are in the hands of terrorists or rogue states. Thus, the existence of nuclear stockpiles in the former Soviet Union (FSU), nuclear testing by India and Pakistan, North Korea's recent violation of the 1994 Agreed Framework, Iran's declaration of its intent to control the entire fuel cycle, the International Atomic Energy Agency's inability to monitor covert nuclear programs in Iraq and North Korea, and growing concerns over the control and protection of fissile materials impose a capability requirement on the Department of Defense. The questions then are:

- How will nuclear arms control look in the future as defined by international trends, "Joint Vision 2020," the latest "Quadrennial Defense Review," the most recent statement of the National Security Strategy, and the first-ever "National Strategy to Combat Weapons of Mass Destruction"?

- What capabilities does the United States require and which of those should reside in the Department of Defense, the Department of Energy, the Department of State, or international bodies such as the International Atomic Energy Agency?

- Which personnel need to be civilian, military, or contracted?

- How should the Department organize and train U.S. military forces to accomplish required weapons of mass destruction inspection missions? 
The answers to the above questions must lead to an executable concept within the framework of doctrine, organization, training, materiel, leadership and education, personnel and facilities of the Joint Vision Implementation Plan, and determine the Army's contribution to this crucial defense activity. This paper restricts its examination of the Army's role to the Nuclear and Cooperative Threat Reduction Branch (OSSN) of the On-Site Inspection Directorate. However, the methodology is applicable to the structuring of forces to control all weapons of mass destruction. The Department of Defense must revisit the on-site inspection paradigm, retain what has worked in the past and still applies, discard what is no longer relevant, and add new elements necessary to address new challenges, threats, and opportunities. Thus, building upon past successes and adapting to encompass a dynamic threat environment, the Department can provide a unique capability in advancing U.S. interests in this vital area.

\section{THREAT ENVIRONMENT FOR WEAPONS OF MASS DESTRUCTION}

The collapse of the Soviet Union in the early 1990s created a highly unstable security environment shaped largely by regional instability in the Balkans, South West Asia, and Africa. President George W. Bush, in his 2002 State of the Union address, further identified Iraq, Iran, and North Korea as "the world's most dangerous proliferators" of weapons of mass destruction: "States like these and their terrorist allies, constitute an axis of evil, arming to threaten the peace of the world."

In so doing, Bush established that the chief threats to America's security were rogue and non-state actors, seeking to acquire weapons of mass destruction with which to alter the established world order, impose radical Islamic ideology, destroy Israel and create a Palestinian state, and destroy first world states standing in their way. Following the tragic events of 11 September 2001, his speech captured a resolve to wage an aggressive war on terror, which was to be the center piece of the 2002 mid-term elections. More importantly, it elevated the prevention of rogue and non-state actors from acquiring weapons of mass destruction (later identified as preemption in the 2002 national security strategy), as its most important strategic objective. As a result, the establishing of control, safeguards, verification, and transparency over existing weapons and fissile material (along with non nuclear materials) has re-emerged as a top priority for the nation. Since Russia possesses over 95 percent of the world's nuclear weapons and materials outside of the United States, cooperative, bi-lateral, arms control efforts also reclaimed their standing at the nexus of Russo-American engagement. ${ }^{3}$ 


\section{RUSSIA AND THE FORMER SOVIET UNION}

During the Cold War, the Soviet Union produced an extensive weapons and power production complex. The lion share of the production capability and strategic stockpile lay in four states: Russia, Ukraine, Belarus, and Kazakhstan. Fortunately, all of the successor states except Russia terminated their nuclear weapons programs, signed the 1970 Treaty on the NonProliferation of Nuclear Weapons, and turned existing weapons over to Russia -- a major, unprecedented achievement. Russia then accepted responsibility for all remaining weapons. This sequence of events established two pressing priorities for U.S. national and world security: weapon and fissile material accountability (the need to gain control over "loose nukes"), and the need for effective verification.

Independent assessments vary on the amount of material still remaining in Russia. Ashton Carter, former Assistant Secretary of Defense during the Clinton Administration, in his testimony before the Senate Foreign Relations Committee, stated that the Cooperative Threat Reduction funded Mayak facility aimed at entombing "some 20,000 nuclear bomb's worth of plutonium and highly enriched uranium"4 resulting from the Strategic Arms Reduction Treaty. That total constitutes only a "fraction of Russia's huge store of fissile material, enough for a staggering 80,000 bombs. ${ }^{, 5}$ According to the Nuclear Threat Reduction Campaign, "Russia still has enough weapons material to build at least 60,000 nuclear warheads. ${ }^{6}$ In either case, neither of these numbers accounts for tactical nuclear weapons, not yet subject to bilateral treaty reductions and the most likely weapon of choice for nuclear terrorists. Additionally, Russia's research and power producing reactors (including a remaining plutonium production reactor generating power in the Krasnoyarsk region) continue to generate fissile material, which (when separated) only adds to the materials at risk. Thus, the shear quantity of nuclear materials poses a significant threat as a source for nuclear terrorism.

The lack of definitive accountability of existing special nuclear materials compounds the threat posed by the quantity. The great uncertainty associated with the accountability of nuclear weapons and fissile material in the former Soviet Union (from production facilities and retired weapons) has created conditions favorable for diverting material into the hands of rogue states and terrorist networks. The International Atomic Energy Agency evaluated the risk of theft and diversion among the top three risks in nuclear terrorism. Echoing the Agency's assessment, the Nuclear Threat Reduction Campaign's statement cited a recent CIA report that faulted "the security of Russian nuclear arsenal facilities for undetected smuggling." As a consequence, Western states, led by the United States (and especially two farsighted senators, Sam Nunn and Dick Lugar), appropriated millions and now billions of dollars to help Russia gain control 
and reduce the risk that nuclear weapons might fall into malevolent hands. This massive undertaking has been successful by nearly every measure. Still, after eight years of efforts, "only 40 percent of the facilities housing nuclear materials in Russia have received any security improvements through US assistance," of which half are still in progress and not yet completely secure. $^{8}$

In addition to the vulnerability of nuclear materials, Russia has also produced vast amounts of chemical and biological agents, even more susceptible to employment by terrorists, as demonstrated by the use of anthrax attacks in the United States in 2001 and the 1995 sarin subway attacks in Tokyo. Russia has produced "thousands of tons of viruses that cause anthrax, smallpox, and the plague, and at least 40,000 tons of nerve and blister agents. ${ }^{9}$ U.S. and other agencies have yet to determine the full magnitude of the problem as a result of a lack of Russian transparency in chemical and biological weapons (as recently witnessed in the Moscow movie theater incident). As a result, the Bush administration has delayed the start of new Cooperative Threat Reduction programs until the Russians are more forthcoming on chemical and biological programs including those dating back to the Soviet era. ${ }^{10}$

\section{POST 11 SEPTEMBER}

The attacks on the World Trade Center and the Pentagon forever changed the security environment and redefined the unthinkable, as well as the lengths to which terrorists could go. Those acts catapulted Americans from the immediate post Cold War period, in which the United States struggled to develop a coherent, unifying national security strategy. Led by the Clinton administration, the United States practiced preventive measures with North Korea, containment of Iraq, Cooperative Threat Reduction with Russia, the Oslo Accords with Israel and the Palestinian Liberation Organization, and engagement with China. The United States led military peace keeping operations in Bosnia Herzegovina and the NATO air campaign against Serbia in Kosovo. It championed multilateral arrangements, globalization and free markets, and assembled the North American Free Trade Agreement to counter the formation of the European Union. What was missing, however, was a clear, defining threat to impose order, structure, priorities, and direction on U.S. foreign policy and national security strategy.

Though unintended, Al Qaeda's attacks provided the clear, unmistakable threat to U.S. national security with the first attacks on American soil since Pearl Harbor. ${ }^{11}$ Intelligence analysts, justice department officials, and policy makers began to connect the dots systematically and discovered a convergence of rogue states intent on destroying regional stability, non-state terrorist groups willing to use mass destruction to accomplish their goals and 
willing to die in the process, failed states in which terrorist groups could function with little interference, and rogue and non-state actors intent on acquiring weapons of mass destruction through theft, diversion, and purchase from cash-strapped smugglers. President Bush's 2002 State of the Union address provided an unambiguous assessment of current and future threats. Likewise, he identified three rogue regimes that he believes embody the intent and the potential to threaten U.S. interests at home and abroad.

\section{AXIS OF EVIL}

Iraq, Iran, and North Korea constitute President Bush's Axis of Evil. Of the three, Iraq and North Korea occupy center stage in the nonproliferation arena. The United Nations Security Council, led by the United States, authorized economic sanctions, combat operations, and weapons inspections to seize and destroy weapons of mass destruction in Iraq with significant success until Saddam Hussein expelled the inspectors in 1998. Iraq's unwillingness to continue disarmament under United Nations oversight placed it first among equals in the America's strategy to combat the threat of weapons of mass destruction. However, North Korea's recent admission that it possessed a covert nuclear weapons (highly enriched uranium) program -- as well as provocative actions during the 1990's -- makes it the second most pressing object of U.S. foreign policy.

In his 6 May 2002 Heritage Foundation Lecture, John R. Bolton, Under Secretary of State for Arms Control and International Security, stated that North Korea had violated the Biological and Toxin Weapons Convention. He further alleged that North Korea has "developed and produced, and may have weaponized biological agents in violation of the Convention." ${ }^{\text {.12 }}$ Six months earlier, Bolton had charged North Korea for its covert nuclear weapons program in violation of the Nuclear Non-proliferation Treaty:

This year, North Korea did not meet congressional certification requirements because of its continued lack of cooperation with the International Atomic Energy Agency, its failure to make any progress toward implementing the North-South Joint Denuclearization Declaration as called for under the Agreed Framework, and for proliferating long range ballistic missiles. Finally we believe that North Korea has a sizeable stockpile of chemical weapons and can manufacture all manner of CW agents. ${ }^{13}$

Recent intelligence reports have confirmed suspicions that North Korea has violated its obligations to the international agreements to which it is a party. When confronted, the North Koreans acknowledged that they have been pursuing a nuclear weapons program for the past 
several years, after first vehemently denying the charge. The executive board of the Korean Peninsula Energy Development Organization condemned North Korea for "pursuing a program to produce highly enriched uranium for nuclear weapons..."14 and cited its actions as "a violation of its obligations under the Agreed Framework, the Nuclear Non-proliferation Treaty, and the Joint South-North Declaration."15

These developments, along with the Spanish interception of North Korean ballistic missiles en route to Yemen, underlined North Korea's role as a major contributor to the proliferation of weapons of mass destruction. ${ }^{16}$ Its willingness to sell arms and technology as well as a covert nuclear production program, makes it a likely source from which rogue and non state actors could acquire weapons of mass destruction. Not to be forgotten, Iran recently admitted that it had embarked on a program to control the entire nuclear fuel cycle. Secretary Bolton announced U.S. concerns that Iran was "seeking all elements of a nuclear fuel cycle, from mining uranium to enrichment to production of reactor fuel," at the summer 2002 Group of Eight (G-8) summit in Canada. ${ }^{17}$ Six months later, International Atomic Energy Agency director Mohamed El Baradei traveled to the Natanz nuclear facility, and verified Iranian opposition group reports that Iran was completing construction of a gas centrifuge plant capable of producing enriched uranium. Iran's actions, combined with declarations that it "intends to activate a uranium conversion facility near Isfahan...to produce uranium hexaflouride gas (for use in the enrichment process)," suggest that Iran was developing a covert nuclear program to produce uranium weapons, while the International Atomic Energy Agency was focused on safeguarding declared activities. ${ }^{18}$

Rogue states are but one, albeit important, source of material at risk to terrorists seeking to use weapons of mass destruction against the United States. Ash Carter points out that the post 11 September environment includes materials from Pakistan and India, states which have built nuclear arsenals to deter their neighbors, non-rogue states from Ghana to Serbia possessing research reactors, and other non-nuclear weapons states including allies such as Japan and Belgium possessing plutonium byproducts of their nuclear power programs. ${ }^{19}$ These, along with radioactive sources used in medicine, industry, and other peaceful pursuits, could provide radioactive materials to terrorists just as easily. In sum, the wide availability of nuclear, radiological, chemical, and biological materials constitutes a greater threat in this post "9/11" world. Thus, the United States requires a strategy based upon capabilities that address a multitude of threats and employ instruments capable of defeating the threat of weapons of mass destruction at their origin. Though a relatively recent development, the history of on-site 
inspection demonstrates considerable potential for verifying accountability, control, and destruction of materials and weapons of mass destruction.

\section{ON-SITE INSPECTION}

Some government and security analysts erroneously look back on the bi-polar security environment that dominated the Cold War with a sense of nostalgia, when contemplating the unstable, multi-threat environment which characterizes the twenty-first century. In this new environment, weapons of mass destruction pose a great threat to the world's security and stability, as the Bush administration's recently published National Security Strategy indicates. ${ }^{20}$ Weapons of mass destruction constitute a threat in the hands of terrorist groups and rogue states, sources which nonproliferation policies aimed at countering. However, the existence of weapons of mass destruction also poses a threat from non-rogue states. These include traditional, first-world powers as well as states seeking prestige through the acquisition of such capabilities. Many have already developed chemical, biological, or nuclear weapons. Unless reduced and controlled, these weapons could find their way into the hands of those willing to use them. Fortunately, on-site inspections have proven effective in reducing the threat.

On-site inspection represents a key military instrument in America's national security strategy. Not withstanding the difficulties experienced in Iraq, it remains a vital instrument and could contribute to the combating of the proliferation of weapons of mass destruction in states that recognize the threat posed by such weapons. On-site inspections serve as the steel that strengthens treaties and builds confidence among participants. Thus, U.S. policy makers should retain and support on-site inspections as a viable strategic concept, worthy of expansion to reduce the threat among states with the added benefit of reducing stocks that might become available to rogue states and terrorists (foreign and domestic).

\section{BILATERAL ON-SITE INSPECTIONS}

On 8 December 1987, Presidents Ronald Reagan and Mikhail Gorbechev signed the historic Intermediate-Range Nuclear Forces Treaty in Washington, D. C. "The treaty eliminated an entire class of ground launched intermediate-range and shorter-range missiles and their launchers and prohibited possession of such systems thereafter. ${ }^{21}$ According to the treaty, intermediate and shorter range weapons were those in excess of 500 kilometers but not greater than 5,500 kilometers. It also provided "an extensive and, for the time, unprecedented regime of on-site inspections. ${ }^{122}$ 
In conjunction with monitoring and national technical means, the newly conceived on-site inspections became a critical component of verification and the subsequent determination of compliance by the treaty partners. The on-site inspection provision led to the creation of the OnSite Inspection Agency under the Office of the Secretary of Defense. That office was to verify compliance by the fifteen successor states of the Soviet Union. Russia, Kazakhstan, Belarus, and Ukraine assumed the roles of active implementers. ${ }^{23}$ Colin Powell, as the National Security Advisor to President Reagan, recommended that the On-Site Inspection Agency become a part of the Department of Defense with a uniformed director and deputy directors from the Departments of State (Arms Control Disarmament Agency), Energy, and the FBI. Army and Air Force lieutenant colonels led interagency teams consisting of weapons inspectors and experts from relevant government agencies. Thus, the On-Site Inspection Agency, joint and interagency in character, grew out of the National Security Council and the interagency process.

The Intermediate-Range Nuclear Forces Treaty's on-site inspection provision proved to be highly effective and included baseline (to verify data declarations), close out, short notice, elimination, and around the clock inspections "at any facility at which the production or final assembly of a prohibited Ground-Launched Ballistic Missile occurred. ${ }^{24}$ As a result of thirteen years of inspections ( 851 by the United States and 540 by the Soviet Union and its successor states), the parties have confidence that both sides have complied; the United States has eliminated 2,332 treaty limited items and the former Soviet Union 5,439 items. Of the treaty limited items, the inspectors verified that 846 U.S. missiles (Pershing $1 \mathrm{~A}$ and IB, Pershing II, and BGM-109G GLCM) and 1,846 former Soviet Union missiles (SS-4, 5, 12, 20, 23 and SSCX-4 GLCM) were destroyed. ${ }^{25}$

Without question, on-site inspection demonstrated considerable utility under the Intermediate-Range Nuclear Forces Treaty when applied in the context of willing states who saw it in their individual and collective interests. When combined with other verification means, it became a powerful national security tool in eliminating the threat presented by intermediaterange and shorter-range nuclear weapons. Risk depended in large part on the cooperation of treaty partners and a shared interest in reducing the threat of nuclear annihilation, especially when confronted with the Soviet Union's collapse. Success also depended on a number of other verification means, supporting and directing on-site inspection efforts. As a result, the combined effect reduced the risk and contributed to the growth of a highly effective inspection regime, modified and largely replicated in subsequent treaties. 


\section{MULTILATERAL ON-SITE INSPECTIONS}

In contrast to the success of on-site inspections under the Intermediate-Range Nuclear Forces Treaty and subsequent nuclear (Threshold Test Ban Treaty, Peaceful Nuclear Explosions, Strategic Nuclear Arms Reduction Treaty) and conventional (Conventional Forces Europe) treaties, U.S. policy did not support legally binding declarations and aggressive, robust, and short notice on-site inspections in the class of multilateral agreements designed to reduce the threat of weapons of mass destruction. ${ }^{26}$ These include the Chemical Weapons Convention, Biological and Toxin Weapons Convention, and the Comprehensive Test Ban Treaty. The Biological Weapons Convention, for example, "forbids its 144 member states from developing, retaining, and transferring" biological weapons. ${ }^{27}$ Crafted in 1972, it asserted that "use of biological weapons would be repugnant to the conscience of mankind and that no effort should be spared to minimize this risk. ${ }^{28}$ However, the absence of on-site inspections and tougher, legally binding provisions enabled thirteen states (including seven member states) to violate the convention without serious repercussions. ${ }^{29}$

Characteristic of the current Bush administration's policies regarding multilateral agreements prior to September 2001, the U.S. supported weaker, less politically binding provisions and opposed rigorously enforced declarations. Consequently, the United States derailed international efforts mounted to strengthen the Biological Weapons Convention. Fortunately, the events of 11 September 2001 have altered U.S. national security strategy. The Bush administration has emphasized the role of multilateral cooperation when it launched the War on Terror by mobilizing a coalition of willing nations around the world. The world observed the administration's shift in policy from the threat of unilateral use of force to a concerted effort to win international support prior to taking military action against Iraq. President Bush challenged the United Nations to hold Iraq accountable for failing to comply with legally binding resolutions and won a 15-0 unanimous vote in the Security Council (which included nations as ideologically opposed to the United States as Syria). Accordingly, U.S. policy makers should revisit international non-proliferation regimes and advocate rigorous on-site inspection provisions and other verification means (e.g., legally binding declarations) to reduce the threat of weapons of mass destruction in the Biological Weapons Convention, Comprehensive Test Ban Treaty, and Chemical Weapons Convention. If necessary, the United States should engage the Conference on Disarmament to strengthen provisions while inserting language and taking measures to protect U.S. security and commercial interests where wanting.

The nuclear non-proliferation arena, the United States entered a number of bilateral and multilateral agreements designed to stem the production of fissile material, testing, and the flow 
of missile technology and components worldwide. ${ }^{30}$ The U.S. Arms Control Disarmament Agency, supported by the Interagency, (in conjunction with the Conference on Disarmament and other interested parties) took the lead and laid out the road map, a comprehensive plan to control each element of the nuclear fuels cycle necessary to build weapons. ${ }^{31}$ The cycle consists of uranium mining, reactors, enrichment (in the case of highly and lowly enriched uranium [HEU/LEU]), plutonium reprocessing, pit design and assembly, missile technology export controls, and storage of material from weapons taken out of the stockpile. The agreements designed to address these elements of the nuclear fuel cycle include extant treaties such as the Threshold Test Ban Treaty, the Strategic Arms Reduction Treaty, and the Agreement to Shutdown Plutonium Production Reactors. Future agreements will address the other aspects of nonproliferation to include the Fissile Material Cutoff Treaty (a.k.a. FISSBAN), Enhanced Missile Technology Control Regime, and initiatives currently grouped under the rubric of safeguards, transparency, and irreversibility such as Strengthened International Atomic Energy Agency Safeguards and Mayak Transparency. ${ }^{32}$ A mix of bilateral and multilateral agreements, they represent diplomatic efforts to serve U.S. interests by preventing nuclear proliferation.

While the results are mixed, two things are clear: rigorous verification and legally binding provisions are indispensable for successful non-proliferation and arms control regimes; and the requirement for on-site inspection will continue into the foreseeable future. Concerns over sovereignty and other issues of interest to Congress and others-particularly prior to 11 September, had constrained U.S. involvement in multilateral agreements. Likewise, the administration's appetite for time consuming international negotiations through organs such as the United Nations and the Conference on Disarmament was nearly nonexistent. However, the advantages accrued in its efforts to assemble a "coalition of the willing" and remove the Taliban regime in Afghanistan should be sufficient to convince skeptics that unilateralism works against U.S. long term interests in garnering international support and legitimacy. More to the point, unilateral action will not enable the United States to accomplish its most important objectives. Accordingly, one must view multilateral agreements at least as a necessary evil warranting U.S. involvement and commitment in order to insure they serve the national interests (e.g. define the scope and treaty limits, shape the language, etc.).

INTERNATIONAL ATOMIC ENERGY AGENCY STRENGTHS AND WEAKNESSES

The International Atomic Energy Agency safeguards program is a vital United Nations' organ designed to increase confidence that nations remain in compliance with the Nuclear 
Nonproliferation Treaty and peaceful uses of nuclear material. It possesses the requisite expertise to monitor and administer programs for non weapons state signatories. ${ }^{33}$ Thus far, it has proven to be highly effective when nations willingly submit to oversight of their programs. The United States also supported the use of the International Atomic Energy Agency as a means of gaining control of peaceful nuclear programs around the world (with hopes of convincing Russia that placing material under International Atomic Energy Agency safeguards would serve Russian as well as world security interests). Unfortunately, countries such as Iraq and North Korea, both signatories as non weapons states, have pursued non peaceful purposes and concealed their efforts without detection, while under the safeguards program.

The case of Iraq, in particular, raises questions about the International Atomic Energy Agency's ability to provide confidence for the international community concerning rogue states who sign the Nuclear Nonproliferation Treaty with no intention to fully comply, or that change their intention without withdrawing from the Nuclear Nonproliferation Treaty. Before and after the Gulf War, Iraq engaged in a series of deceptions undetected by International Atomic Energy Agency monitors, while simultaneously earning International Atomic Energy Agency praise for compliance. As an example, "... only weeks after Iraq invaded Kuwait, International Atomic Energy Agency safeguards director Jon Jennekens praised Iraqi cooperation....as exemplary...a solid citizen under the Nuclear Nonproliferation Treaty. ${ }^{34}$ After DESERT STORM, the International Atomic Energy Agency learned along with the rest of the world that Iraq had continued its pursuit of nuclear weapons under International Atomic Energy Agency's nose. In 1993, after destruction of the discovered plants, the International Atomic Energy Agency Director General, Hans Blix, again asserted that Iraq had changed its ways. He stated that the Iraqis had not tampered with highly enriched uranium under International Atomic Energy Agency safeguards. Yet again, the International Atomic Energy Agency had been unable to detect Iraqi efforts proven by the defection of Saddam Hussein's son-in-law, General Hussein Kamel. Kamel testified to the United Nations Security Council that he had been the director of a "crash program" to build a crude nuclear weapon from International Atomic Energy Agencysafeguarded material. ${ }^{35} \mathrm{He}$ also admitted to cutting the ends off the highly enriched uranium rods which would have enabled the Iraqis to assemble a SCUD mounted nuclear warhead within a month, had they not been halted by Coalition bombing during DESERT STORM.

Admittedly, the risk that states could violate treaty constraints (or not fulfill all obligations) without detection exists even with strengthened provisions. Obviously, Iraq demonstrates how the safeguards arrangement which worked well in most instances, fails under conditions in 
which the signatory has no intention of complying. Likewise, North Korea reinforces this important limitation in International Atomic Energy Agency-like protocols.

Nevertheless, the status quo is far worse, relying only on intelligence estimates as is the case with the Biological Weapons Convention: "With treaty violations on record and too few effective ways to monitor compliance and legally enforce the Biological Weapons Convention, ${ }^{36}$ states routinely disregard requirements to submit declarations. Thus, conventions alone will not suffice to provide confidence that states will fulfill their obligations. To address this shortfall, proponents of tougher inspections, broader mandates and legally binding declarations argue that added on-site scrutiny will deter countries from pursuing illegal programs. In effect, tough standards provide the incentive for compliance with international norms.

The goal of reducing and eliminating the threat of weapons of mass destruction ranks among the top strategic objectives and policy priorities facing the United States Government. The use of on-site inspections under the Intermediate-Range Nuclear Forces Treaty provided the rigor, incentive, and confidence to reduce the threat of nuclear weapons of mass destruction. In contrast, their absence multiplied the threat under the Biological Weapons Convention. As the international community grapples with the need to expand and strengthen nonproliferation regimes in the wake of 11 September, it will look to the United States for leadership in crafting tougher provisions to provide the confidence that neither rogue nor nonstate actors possess weapons of mass destruction. Therefore, the Department of Defense must retain and expand on-site inspections, in conjunction with other verification means, as an effective, confidence building engine toward reducing and eliminating the threat of weapons of mass destruction. The Defense Threat Reduction Agency's On-Site Inspection Directorate (the Defense Threat Reduction Agency/OS) is the repository of U.S. knowledge, and expertise upon which to build a new strategic concept for combating weapons of mass destruction.

\section{NUCLEAR THREAT INITIATIVE}

Given the strategic environment described above, the United States must develop and implement a coherent strategy designed to meet a number of weapons of mass destruction threats. A number of concepts now compete in universities, think tanks, government bureaucracies and the international press for acceptance at home and abroad. Of those, two have particular merit and suggest capability requirements for the Department of Defense and the Interagency: the Nuclear Threat Initiative and the Nuclear Threat Reduction Campaign. Additionally, the Nuclear Control Institute has raised important questions about International 
Atomic Energy Agency verification activities that bear consideration when evaluating new concepts.

Founded in January 2001 as a non-profit foundation, the Nuclear Threat Initiative exists to fill the gap between the threats from nuclear, chemical, and biological weapons and the global response. Co-chaired by former Senator Sam Nunn and Ted Turner, it attempts to foster cooperation amongst diverse people, organizations, and governments around this common threat, and to develop a plan for immediate action. Owing in large part to his considerable experience in the United States Senate, Senator Nunn has assembled an impressive coalition of able diplomats, scientists, policy experts and academics. His international Board of Directors consists of members from the United Kingdom, Sweden, Pakistan, Japan, and Jordan to name a few. He also boasts two sitting senators, two members of the Russian Duma, a Nobel Prize winning economist, and a former Secretary of Defense. ${ }^{37}$ Together, they have made a cogent argument for how the Bush administration should proceed to win the war on terror and deny weapons of mass destruction to terrorists and rogue states.

The Nuclear Threat Initiative proposal argues that if weapons of mass destruction are in fact the number one threat facing U.S. national security, then the United States should immediately appropriate funds sufficient to reduce the vulnerability- sooner, rather than later. The events of 11 September make it clear that no nation regardless of geography, economic power, or military might is secure, immune to this threat. It is a shared threat and requires a shared solution. Further, since the United States and Russia created the majority of weapons of mass destruction during the Cold War arms race, they should lead what the Nuclear Threat Initiative calls the "Global Coalition Against Catastrophic Terrorism. ${ }^{, 38}$

In looking for concepts which have worked in the past, Senator Nunn had to look no further than the Cooperative Threat Reduction program. Funded by legislation sponsored by himself and Dick Lugar in November, 1991, the Cooperative Threat Reduction program was a radical experiment for reducing threats in a cooperative way that. In essence, the program tied financial assistance to treaty limited reductions of weapons and infrastructure. It included everything from biological weapons labs, nuclear reactors and missiles to export control, emergency response and storage facilities. It successfully bridged relations between Russia and the United States even when the political winds shifted during Operation Allied Force. However, more remains to be done. If expanded and shared with other nations, the program could complete the task in Russia and beyond in relatively short order. Thus, the Nuclear Threat Initiative's Global Coalition Against Terrorism poses six urgent tasks for U.S. leadership: 
- Secure all nuclear, biological and chemical weapons materials everywhere they exist in the world.

- Reduce the number of US and Russian tactical nuclear weapons, and secure and account for any that remain.

- Build a firebreak against any launch of nuclear weapons by accident or miscalculation by taking as many nuclear weapons as possible off hair-trigger alert in the United States and Russia.

- Strengthen global public health systems, as well as undertake an Apollo-scale research program into vaccines, treatments, and the science of biology, so that we can immediately respond to infectious disease epidemics occurring naturally or from biological terrorism.

- Establish global norms and standards for handling and scientific use of dangerous biological pathogens to prevent these materials from being used by terrorists.

- Complete the destruction of U.S. and Russian chemical weapons which together account for over 90 percent of all of the world's chemical weapons. ${ }^{39}$

In a related collaboration between Harvard's Kennedy School of Government and Stanford University, the Preventive Defense Project posits similar approaches to "address the lethal legacy of Cold War weapons of mass destruction, and counter weapons of mass destruction proliferation and potential acts of catastrophic terrorism. ${ }^{\star 40}$ Ash Carter, the Preventive Defense Project co-chair, has elaborated his vision of the Nuclear Threat Initiative's global coalition. Patterned after President Bush's coalition against terror, the coalition includes every nation possessing materials that terrorists or rogue states could use in weapons of mass destruction. It extends the reach of every nation around the world and includes those who share an interest in preventing terrorists from acquiring dangerous materials, even if they do not possess an indigenous source. Nations would

contribute to the coalitions' activities commensurate with its capabilities and traditions,...cooperate to combat terror in all phases-prevention, detection, protection, interdiction, and cleanup... and agree to world-class standards for protecting fissile material and safeguarding pathogens... ${ }^{41}$

In Securing Nuclear Weapons and Materials: Seven Steps for Immediate Action, Matthew Bunn, John Holdren and Anthony Wier strongly endorsed the scale of effort envisioned by the 
Nuclear Threat Initiative. They urge the United States to lead an international effort to establish "stored weapons standards, ${ }^{, 42}$ for all nations to apply. In order for these

...stringent international standards to have real teeth, there would have to be some means to confirm, or at least to build confidence, that the standards were being met. Measures toward this end could include exchanges of information about nuclear security procedures and standards, and bilateral or international visits or reviews at selected facilities, with managed access to protect sensitive information. ${ }^{43}$

The development and propagation of an international stored weapons standard, in conjunction with an effort on the scale of the Nuclear Threat Initiative, provides the "gold standard." Having earned certification that a nation has met the standard, the world will begin to have fact based confidence that materials are secure.

The Nuclear Threat Reduction Campaign, a project of the Vietnam Veteran's of America Foundation, has a similar agenda to the Nuclear Threat Initiative. As the only Congressionally chartered organization for Vietnam veterans, it has unique access to policy makers to advance its agenda of humanitarian projects emanating from its vision of healing war torn societies, eliminating the threat of landmines to non combatants, and securing justice for military veterans. The focus of the Nuclear Threat Reduction Campaign, however, is the control of weapons of mass destruction at the source. The Nuclear Threat Reduction Campaign seeks U.S. leadership to secure all weapons of mass destruction in Russia by:

- Developing a comprehensive nuclear inventory in Russia (including tactical/portable weapons) of weapons and materials, develop data exchanges of American and Russian stockpiles to ensure safe storage and ultimate elimination where appropriate.

- Passing the Debt Reduction for Nonproliferation Act sponsored by senators Lugar and Biden to swap U.S. debt for Russian investment in domestic non-proliferation activities.

- Signing a legally binding agreement with Russia to reduce outdated stockpiles of strategic nuclear weapons held by the US and Russia.

- Strengthening Cooperative Threat Reduction program funding to secure and neutralize Russian nuclear weapons and materials and find peaceful employment for Russian Scientists and technicians. 
- Reducing the threat of bio-terrorism by expanding existing programs and developing mechanisms to strengthen cooperation to prevent proliferation of biological weapons, materials, and expertise. ${ }^{44}$

In essence, the Nuclear Threat Reduction Campaign champions the expansion of the Nunn-Lugar-Domenici legislation which expands the scope and funding of the Cooperative Threat Reduction program in Russia. Ambassador Karl Inderfurth, former Assistant Secretary of State for South Asian Affairs from August 1997 to January 2001, serves as the Nuclear Threat Reduction Campaign Senior Advisor. In his testimony before the Senate Foreign Relations Committee hearing on the Strategic Offensive Reductions Treaty (SORT a.k.a. Moscow Treaty), Ambassador Inderfurth stated that "We simply will not rid the world of the greatest threat to humanity until all of Russia's nuclear weapons and material have been accounted for and secured. ${ }^{, 45} \mathrm{He}$ also called for transparency and verification imperatives missing from the Strategic Offensive Reductions Treaty. Finally, he cited Senator Nunn's testimony and recommended verification procedures for the three year gap that exists between the 2009 expiration of Strategic Arms Reduction Treaty verification provisions and the 2012 Strategic Offensive Reductions Treaty expiration for which no other verification provisions currently exist. ${ }^{46}$

Both the Nuclear Threat Initiative and Nuclear Threat Reduction Campaign agree on the need to attack the threat of weapons of mass destruction proliferation at the source. However, while the Nuclear Threat Reduction Campaign constrains its policy recommendation to a bilateral prescription, the Nuclear Threat Initiative uses bilateral achievements to establish a world wide, multilateral coalition that harnesses the shared interests and vulnerability of citizens and governments around the world. Given the early successes of Bush's coalition against terror, the Nuclear Threat Initiative's global coalition should have similar success being led by both the United States and Russia.

From Spain's interception of the ballistic missiles en route from North Korea to Yemen, the participation of NATO countries in Afghanistan, and the broad intelligence cooperation leading to the arrest of suspected terrorist cells from Canada to the Philippines, the shared threat of terrorism unifies nations across the political landscape. Consistent with the international cooperation required to make it successful, the Nuclear Threat Initiative has sought to bolster the International Atomic Energy Agency to place extant nuclear materials under International Atomic Energy Agency safeguards with adequate funding to accomplish the massive task. Given International Atomic Energy Agency's track record, however, careful consideration should 
be given to insure the International Atomic Energy Agency's responsibilities are limited to its areas of demonstrated competence.

The Nuclear Control Institute has long been a critic of the International Atomic Energy Agency for its performance in Iraq and North Korea. As described in earlier, the International Atomic Energy Agency repeatedly failed to detect covert activity in both cases. Steven Dolley, the Nuclear Control Institute's Research Director, published an in-depth analysis of nuclear inspection in Iraq entitled "Iraq and the Bomb: The Nuclear Threat Continues" dated February 19,1998 . He described the friction that developed between the United Nations Special Commission on Iraq inspectors and International Atomic Energy Agency inspectors. ${ }^{47}$ United Nations Special Commission on Iraq included members of the U.S. On-Site Inspection Agency (now part of the Defense Threat Reduction Agency), military professionals with extensive inspection experience. United Nations Special Commission on Iraq inspectors approached inspections in a tough, hard nosed manner. Rolf Ekeus, the United Nations Special Commission on Iraq Chief Executive Officer in 1997, stated that United Nations Special Commission on Iraq inspectors were "... by nature suspicious" ${ }^{48}$ in their approach motivated by an understanding that if Iraq had in fact solved the warhead design problem, they then had the technology to create a viable implosion weapon, a significantly greater threat. In truth, United Nations Special Commission on Iraq was "more confrontational, refusing to accept Iraqi obfuscations and demanding evidence of destroyed weapons. ${ }^{\wedge 9}$

In contrast, the International Atomic Energy Agency inspectors approached inspections from a completely different point of view. Theirs was a cooperative, collegial approach between members of a shared scientific community. Since both United Nations Special Commission on Iraq and International Atomic Energy Agency both conducted nuclear inspections, the friction became a major impediment to agreement on key findings and observations. After leaving the United Nations Special Commission on Iraq, Ekeus stated that "better coordination and consultation between the two agencies would be required if the remaining questions about the Iraqi program are to be answered. ${ }^{50}$ Nevertheless, the United Nations Security Council awarded the nuclear inspection portfolio to the International Atomic Energy Agency with U.S. support to advance the extension of the Nuclear Nonproliferation Treaty. The conventional wisdom asserted that giving United Nations Special Commission on Iraq the mission would have undercut the International Atomic Energy Agency and irreparably damaged the Nuclear Nonproliferation Treaty at a time when its survival was in question.

To compound matters, the International Atomic Energy Agency "seems to place an almost naïve confidence in the absence of evidence contradicting unsubstantiated Iraqi claims" when 
the presumption should be to continue investigation until evidence mounts to positively and conclusively confirm Iraqi claims of compliance.$^{51}$ As an example, Ekeus considered it reasonable to demand evidence confirming the destruction of nuclear components in his 1997 statement holding the Iraqi's accountable for providing such proof:

Iraq produced components, so to say, elements for the nuclear warhead. Where are the remnants of that? They can't evaporate...We feel that Iraq is still trying to protect them. And that is part of our ...efforts...to find these remnants... We know that they have existed. But we doubt they have been destroyed. But we are searching. ${ }^{52}$

This approach runs counter to International Atomic Energy Agency values. As a result, the Iraqi's were able to conduct covert activities with impunity.

Thus, Ekeus and Dolley correctly fault the International Atomic Energy Agency culture for the success of Iraqi covert activities while under safeguards, before and after DESERT STORM. As a result, suggestions to use the International Atomic Energy Agency under circumstances which require it to act contrary to its nature is a flawed proposition with predictable results. It does most things well. Conducting inspections and monitoring safeguard programs for nations likely to pursue covert development programs and would-be proliferators are not among their past successes.

In contrast, United Nations Special Commission on Iraq-like organizations do possess the requisite competence and appropriate disposition to successfully serve US interests in countries with dubious intentions and track records. The US should retain the ability to resource United Nations Special Commission on Iraq-like international inspectorates to insure its interests are protected. As a note, the United Nations Monitoring and Inspection Commission does not pass this test. Hans Blix, the Executive Chairman of United Nations Monitoring and Inspection Commission, served as the International Atomic Energy Agency Director General from 1981 to 1997, the period in question. His appointment, along with provisions precluding the US from contributing inspectors that will meet the standard articulated above, renders the United Nations Monitoring and Inspection Commission impotent, incapable of accomplishing the formidable task of carrying inspections four years after Iraq expelled inspectors in 1998.

The policy proposals from the Nuclear Threat Initiative, Nuclear Threat Reduction Campaign, Preventive Defense Project and the Nuclear Control Institute, combined with the Bush administration's declared strategy, make a clear case for retention of key arms control capabilities resident in the Department of Defense and her sister departments of State, Energy, and Justice. Rather than relegate arms control to the past as a Cold War relic, these proposals demand proven capabilities for traditional verification activities through $2012 .^{53}$ More 
importantly, the Nuclear Threat Initiative argues the application of arms control concepts to a broader, more pressing array of threats and scenarios.

\section{MEETING THE NUCLEAR CHALLENGE}

In December 2002, the Bush Administration published its National Strategy to Combat Weapons of Mass Destruction. It contains the administration's growing appreciation of the need to combat weapons of mass destruction at the source, as well as the requirement to respond to use against the United States and its allies. The strategy contains three main pillars. Of the three, 'Strengthening Nonproliferation to Combat Weapons of Mass Destruction Proliferation' directly captures the U.S. commitment to reengage in multilateral and bilateral arrangements with the necessary provisions to make them effective. In addition to urging the broader international community to prevent terrorists from acquiring weapons of mass destruction, the administration pledges to "... enhance traditional measures-diplomacy, arms control, multilateral agreements, threat reduction assistance, and export controls-that seek to dissuade or impede proliferant states and terrorist networks... and ensure compliance with the Nuclear Nonproliferation Treaty, the Chemical Weapons Convention, and the Biological Weapons Convention." ${ }^{54}$ More significantly, the strategy commits the United States to "support those regimes that are currently in force, and work to improve the effectiveness of, and compliance with, those regimes....and will also promote new agreements and arrangements that serve our nonproliferation goals. ${ }^{, 55}$

In the nuclear arena, U. S. goals include:

- Strengthening of the Nuclear Nonproliferation Treaty and International Atomic Energy Agency, including through ratification of an International Atomic Energy Agency additional protocol by all Nuclear Nonproliferation Treaty states parties, assurances that all states put in place full-scope International Atomic Energy Agency safeguards agreements, and appropriate increases in funding for the Agency.

- Negotiating a Fissile Material Cut-Off Treaty that advances U.S. security interests; and Strengthening the nuclear suppliers Group and Zangger Committee. ${ }^{56}$ 
These measures demonstrate the administration's recognition that working within international frameworks constitutes an indispensable component of U.S. strategy. Combined with unilateral and bi-lateral commitments, they contribute to a wide range of options from which to choose. Further, they acknowledge that solving global problems requires U.S. leadership, enforceable legal constructs and international norms, and a global strategy. It includes expanding efforts such as the Nunn-Lugar Cooperative Threat Reduction program and the G-8 Global Partnership Against the Spread of Weapons and Materials of Mass Destruction "...designed to address the proliferation threat stemming from the large quantities of Sovietlegacy weapons of mass destruction and missile related expertise. ${ }^{57}$

In sum, the Bush Administration's shift in policy as articulated in both the National Security Strategy and The National Strategy to Defeat Weapons of Mass Destruction necessarily requires a review of Department of Defense programs and policies, joint and service organizations, and doctrine and training to achieve the president's policy objectives. As a starting point, the review must begin with whether the Defense Threat Reduction Agency possesses the capabilities to match the counterproliferation and nonproliferation policies that flow from the president's strategy. The On-Site Inspection Directorate, the arm of the agency that implements arms control and nonproliferation policies through on-site inspections and technical assistance, must adapt to the changing security environment, new strategic imperatives and the changing face of on-site inspections.

The history of on-site inspections between the United States and the Soviet Union (and its successor states), the widely acclaimed Cooperative Threat Reduction program, as well as the United Nations Special Commission to Iraq, suggests the existence of three distinctly different classes of inspections defined by level and degree of cooperation. Ranging from obstruction and clear opposition on one end and cooperative partnership on the other, they can best be categorized as adversarial (or imposed), reciprocal, and cooperative on-site inspection regimes. 


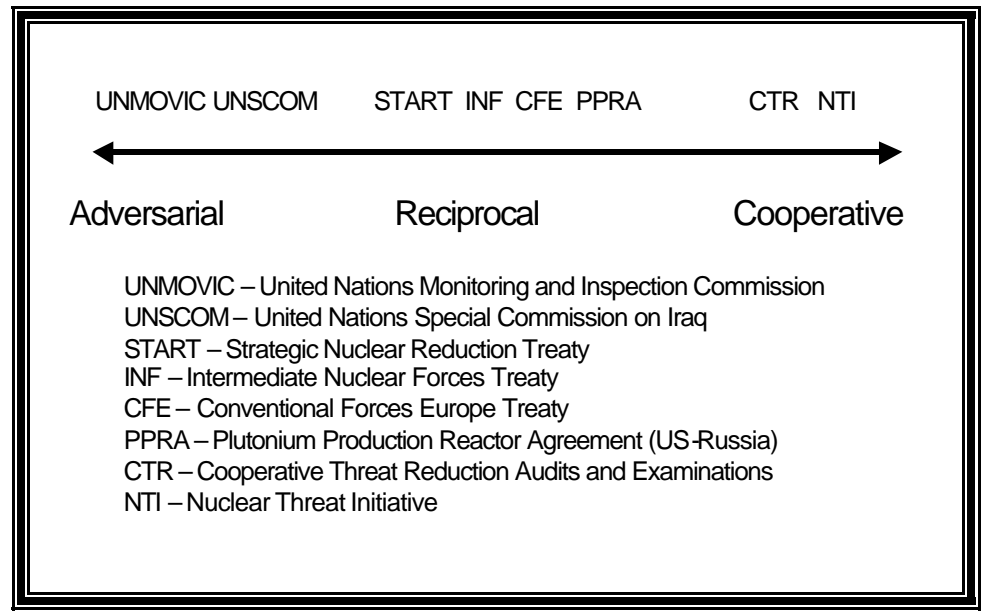

FIGURE 1: ON-SITE INSPECTION CONTINUUM

They possess different characteristics and limitations and serve different purposes.

Understanding the differences should enable force developers and planners to size, train and equip forces to accomplish the missions flowing from the strategy. At the operational level, understanding the differences will enable leaders to properly tailor on-site inspections to suit the political context of each situation. Finally, given the defense department's leading role in the National Strategy to Combat Weapons of Mass Destruction, it should immediately structure onsite inspection forces to satisfy the peculiar requirements of all three classes of nuclear on-site inspection regimes.

\section{ADVERSARIAL ON-SITE INSPECTION}

In the aftermath of the Gulf War, the United Nations Security Council developed and implemented an on-site inspection regime following allied victory over Iraqi forces. Imposed on a militarily defeated Iraq, United Nations inspections achieved significant, though far from complete results. Reluctantly, Iraq submitted to inspections under duress and the threat of force. According to Robert Gallucci, former United Nations Special Commission Deputy Executive Director from 1990 to 1991, inspectors enjoyed five to six years in which inspections were "incredibly effective. ${ }^{.58} \mathrm{He}$ attributes their effectiveness to a unified United Nations Security Council (particularly the permanent members), popular support in the region, international community, and the United States, and the threat of hostilities.

These conditions describe a political context in which on-site inspection can be effective with an adversarial, non-cooperative government. Inspectors verify government declarations 
and "discover" undeclared activity based on a presumption of deceit, lies, and the existence of covert activity, materials and programs. However, analysis of U. N. activities in Iraq suggests three factors which will determine the effectiveness of adversarial inspections.

Adversarial inspections must be accompanied by a credible threat of force (or equivalent sanction depending on the nature of the political regime), time to discover hidden activity, and most importantly, political resolve (or strong consensus in a multilateral context). The discovery function, indispensable in adversarial inspections, is inherently intrusive and depends on a credible, coercive threat to submit to inspections. As demonstrated in the Fall of 2002, the threat of force under United Nations Resolution 1441 led Iraq to accept inspections after successfully ridding themselves of inspectors in 1998. Diplomatic efforts 1998, and others in subsequent years, failed to convince Iraq that it was in its interest to permit inspections. It also requires time. As Iraq demonstrated in the years following the Gulf War, nations that grudgingly submit to inspections can delay the process for years. Had Iraq been forthcoming in its declarations, the United Nations Commission on Iraq could have completed its work in work in far less time and with higher confidence. Instead, adversarial on-site inspections took years to piece together intelligence reports, interview scientists and officials willing to trade information for security guarantees, review documents, and investigate sources for acquiring dual purpose technology with which to conduct their work. Consequently, adversarial inspections are investigative in nature and require sufficient time to investigate all potential leads.

Finally, the most important requirement for adversarial inspections to be effective is political will, the support of government and the people. In his unfinished work On War, Carl von Clausewitz established that war and the use of force is an extension of policy and exists within the framework of a trinity: the nation, its army, and its people. ${ }^{59}$ Using the United Nations actions with respect to Iraq following the Gulf War, the policy to remove weapons of mass destruction from Iraq possessed the support of the international community and popular support among people around the world. Consequently, the United Nations under U.S. leadership possessed the will to use force to back inspections, regardless of Iraqi obstructions. As a result, the inspectors successfully discovered and destroyed much of Iraq's weapons of mass destruction programs in an investigative approach that elicited the scope and size of their weapons industry. However, before completing the task of destroying Iraqi capability and all weapons of mass destruction, the political will within the Security Council dissipated and the threat of force ceased to be credible. In the end, Iraq successfully exhausted the will of the international community, expelled the inspectors, and resumed its weapons programs 
unfettered by the United Nations. The confidence generated by years of successful discovery and subsequent destruction of weapons of mass destruction in Iraq quickly faded.

Clearly, adversarial inspections serve a unique set of conditions among on-site inspection regimes. However, it depends upon the synergy gained by a credible threat of force, time, and political resolve. The absence of any one will preclude success. Above all, the often temporary nature of political consensus may undercut the regime before it fulfills its mandate. Rogue states intent on pursuing weapons of mass destruction will undoubtedly resist efforts to curb their programs, especially on-site inspection. Nevertheless, the United States and the international community should pursue diplomacy, and if necessary force, to compel states like Iraq to submit to on-site inspections to remove the threat of weapons of mass destruction from their arsenals.

However, even when all three factors of credible force, time, and resolve are present, the results only remain valid for the duration of the inspection regime absence a change in national goals. This is particularly true with adversarial on-site inspections. As Gallucci made clear, "There is no way they can have a permanent clean bill of health. They don't enter a state of grace..." ${ }^{60}$ Therefore, adversarial on-site inspection only provides confidence for the life of the inspection regime and must be followed by policy changes by the inspected state. Whether resulting from diplomatic, economic, or information elements of power, internal policy changes must occur within the inspected state that preclude a resumption of a weapons program. Additionally, willing submission to a strengthened safeguards monitoring regime of any and all activities that may be used for a weapons program will provide the confidence necessary to secure Gallucci's "clean bill of health."

\section{RECIPROCAL ON-SITE INSPECTION}

The history of the Intermediate Range Nuclear Forces Treaty, and more recently, Strategic Arms Reduction Treaty defines reciprocal arms control regimes forged between the United States and the Soviet Union during the Cold War. President Reagan captured the governing ethos of reciprocal inspections in the phrase, "Trust but Verify" - the motto of the On-

Site Inspection Agency. ${ }^{61}$ Concluded between peer competitors that viewed reductions in their mutual interest, these bi-lateral agreements depended upon on-site inspections supported by intelligence reports and national technical means. Together, they provided the requisite confidence that both sides had complied with their treaty obligations. Aided by Perestroika, Glasnost, and the demise of the Soviet Union, treaty compliance verified by on-site inspections contributed to the creation of a new security environment characterized by Russian and U. S. 
security cooperation. The Strategic Arms Reduction Treaty between the United States and Russia, Ukraine, Belarus, and Kazakhstan, and the Intermediate-Range Nuclear Forces Treaty, exemplify the reciprocal class of on-site inspections. Each side possesses intrusive options to verify the other's claims, declarations, and activities.

Reciprocal inspections, therefore, will remain an important class of on-site inspections for the foreseeable future as Russia and the United States continue to eliminate nuclear weapons in excess of their deterrence needs. As weapon dismantlement continues and requirements for transparency increase, fissile material storage and inspections will lend themselves to reciprocal inspections. Experts from both countries have made considerable progress in finding ways to technically inspect pits, whose shape and composition are protected information. They demonstrated nondestructive assay and shape measurements which could support transparency regimes and provide confidence without compromising classified data.

As more and more nations unveil nuclear programs and weapons, the United States should seek access through some form of reciprocal inspection regime. Obviously, nations that pursue weapons for regional security such as Pakistan and India should enter into bi-lateral treaty regimes with each other. The United States should use its prestige to pass on-site inspection expertise along to both sides via military to military programs. If successful, those efforts could foster transparency, build confidence and security, and decrease tensions in the region.

\section{COOPERATIVE ON-SITE INSPECTION}

Cooperative on-site inspection, the third class of inspections, secured its place as a legitimate confidence building mechanism with the creation of the Nunn-Lugar Cooperative Threat Reduction program. Based on a shared interest in eliminating weapons identified in the Strategic Arms Reduction Treaty, the United States agreed to provide financial assistance at a time when the economies of the Soviet Union's successor states lacked resources to accomplish treaty reductions. After ten years of substantial gains, the Cooperative Threat Reduction program provides the intellectual foundation for the larger, more aggressive Nuclear Threat Initiative. This class of on-site inspection depends on congressional authorizations and commitment to finance and foster desired behaviors in cash-strapped countries. To satisfy congressional oversight, countries receiving U.S. assistance must permit on-site inspections, called audits and examinations under the Cooperative Threat Reduction program, to insure the assistance has been used as intended. The Nuclear Threat Reduction Campaign advocates increasing investment in Russia's efforts to control weapons of mass destruction materials, a 
commitment now embodied in the president's strategy. The Nuclear Threat Initiative seeks to expand this program to developing, resource-poor countries with materials arising from the peaceful uses of nuclear energy.

Cooperative on-site inspection tends to be as intrusive as reciprocal inspections, but without the characteristic resistance. Rooted in a shared interest in reducing the threat posed by nuclear weapons and materials, nations and their agents receiving U.S. assistance often feel free to express their gratitude and work to insure inspectors gain access to satisfy inspection requirements. Even during times of enormous strain between Washington and Moscow, the Cooperative Threat Reduction program functioned well since neither side was willing to jeopardize the program.

Access, therefore, is the key to satisfying on-site inspections. In most cases, U.S. assistance is sufficient to garner access. However, sovereign nations may choose to protect locations and sensitive information. In those instances, the United States sought alternative means to formulate conclusions on intended use. Policy makers must determine whether the alternative methods are adequate to formulate those conclusions. If inadequate, they must choose to either withdraw assistance in those instances or provide it knowing that access will not be forthcoming during on-site inspections. Consequently, determining access prior to awarding assistance should occur with each project in which the United States provides assistance to reduce the threat of weapons of mass destruction under the Nuclear Threat Initiative.

In all three classes of on-site inspection, the United States may determine that bi-lateral inspections satisfy its interests. In most reciprocal arrangements, bi-lateral inspections are the only option. Cooperative arrangements as envisioned by the Nuclear Threat Initiative would quickly exceed the capacity of the United States government to unilaterally accomplish. Consequently, the Nuclear Threat Initiative, advocates initial U.S. (and Russian where possible) leadership to start the process. Once programs mature, and congressional interests have been satisfied, they should be transferred to a multilateral regime. As the new strategy to Combat Weapons of Mass Destruction clearly states, the United States must engage the international community and organizations such as the International Atomic Energy Agency to accomplish this global mission. Accordingly, the Nuclear Threat Initiative envisions a transition from bilateral agreements and inspections with the United States to existing or adapted International Atomic Energy Agency protocols and international monitoring.

Commensurate with the goal of securing all weapons and materials of mass destruction, on-site inspection must encompass a wide array of programs. Whether military or civilian, 
commercial or academic, these programs must conform to standards of accountability, security, and inspection that preclude use by terrorists. Scientists and engineers use nuclear material in reactors to produce commercial power, conduct medical research and treatment, and power ships and submarines. Centrifuges and reprocessing facilities enable governments to produce highly enriched uranium and plutonium, respectively. States must therefore account for, store and immobilize material from spent fuel rods, reprocessed plutonium oxide, enriched uranium and nuclear warheads from decommissioned weapons. Domestically, the Department of Defense, the Department of Energy, and the Nuclear Regulatory Commission perform these functions within their respective sectors. Nations without sufficient resources or mature agencies will likely look to the United States to assist them in building the capacity to deny materials from each sector from terrorist organizations.

The table below summarizes the three types of on-site inspection and the characteristics that define each type. The distinctions of purpose, context, and inspector roles require capabilities within the U. S. government to satisfy each regime. The skills necessary to verify whether assistance provided to secure materials differ from those designed to ascertain the scope and breadth of covert weapons programs. Likewise, the mindset suited to a political context in which nations coerce others to accept inspections differs from the context in which nations seek both assistance and inspections to demonstrate their participation in the global effort to defeat terrorism. Thus, the United States should aggressively resource the Nuclear Threat Initiative, and the recommendations of the Nuclear Threat Reduction Campaign, with the capabilities necessary to execute the strategy. 


\begin{tabular}{||l|l|l|l||}
\hline \hline REGIME & ADVERSARIAL & RECIPROCAL & COOPERATIVE \\
\hline Purpose & $\begin{array}{l}\text { Dismantle programs } \\
\text { and destroy weapons }\end{array}$ & Reduction oriented & $\begin{array}{l}\text { Secure materials and } \\
\text { reductions }\end{array}$ \\
\hline Political Context & $\begin{array}{l}\text { Post/pre-conflict } \\
\text { adversaries }\end{array}$ & $\begin{array}{l}\text { Treaty-defined } \\
\text { partnership }\end{array}$ & $\begin{array}{l}\text { Cooperative, strategic } \\
\text { partnership }\end{array}$ \\
\hline Consent & $\begin{array}{l}\text { Coerced, compelled } \\
\text { by threat }\end{array}$ & $\begin{array}{l}\text { Negotiated by treaty } \\
\text { or agreement }\end{array}$ & $\begin{array}{l}\text { Access given for } \\
\text { assistance }\end{array}$ \\
\hline Inspections & Unlimited & Treaty limited & Agreement limited \\
\hline Inspectors & $\begin{array}{l}\text { Discover weapons } \\
\text { and programs }\end{array}$ & Verify compliance & $\begin{array}{l}\text { Verify intended use } \\
\text { for assistance }\end{array}$ \\
\hline
\end{tabular}

FIGURE 2. ON-SITE INSPECTION REGIMES

\section{THE NUCLEAR AND COOPERATIVE THREAT REDUCTION BRANCH}

With this new direction in combating weapons of mass destruction, the Department of Defense, in cooperation with her sister Departments of State, Energy and Justice, has the ability to implement the president's strategy through the Nuclear and Cooperative Threat Reduction Branch of the Defense Threat Reduction Agency. Reduced in size in 1998 as a result of a questionable agency strategic review, it should now constitute the core of the Department of Defense's efforts to respond to the president's renewed commitment to defeat the threat at the source.

The Defense Threat Reduction Agency leverages the Services and the Interagency to provide the capabilities required by the Nuclear and Cooperative Threat Reduction Branch to perform current missions. The expanded on-site inspection tasks suggested by the Nuclear Threat Initiative will increase the importance of assembling the appropriate on-site inspection expertise:

- Intelligence expertise in state and non state actors analogous to Soviet foreign area officers (e.g., "order of battle" experts with regional [historical and cultural] expertise).

- Nuclear physics and engineering expertise in reactor technology, weapons design and assembly, and storage requirements sufficient to inspect production and storage facilities. 
- Missile, submarine, bomber, and customs and export control expertise.

- Competence in the implementation of relevant nuclear treaties and agreements, bilateral and multilateral.

- Linguists capable of consecutive interpretation, translation, and technical and conversational ability in the languages of treaty parties.

Personnel with capabilities identified above need not come entirely from the Department of Defense. Instead, personnel should be selected from agencies whose core competencies coincide with needed skills and expertise. In light of growing interagency integration down to and including combatant command staffs, the Department of Defense must increasingly leverage interagency capabilities as it structures the nuclear branch while simultaneously increasing the number of military members assigned to sister agencies in complementary programs. As an example, the Department of Defense should provide officers to the Department of Energy in fissile material physical protection, control and accountability programs that broaden the experience of nuclear specialty officers. In the end, critical capabilities increase, cultural barriers fall, and most importantly, the United States increases its security by denying weapons of mass destruction to terrorists and rogue states..

The administration, Congress, and the American people look to the defense department for its ability to train and develop leaders and disciplined professionals: weaponeers, nuclear research and foreign area officers, and linguists. Similarly, the Department of Energy possesses the deepest technical base and should be the primary, though not only, supplier of nuclear scientists and engineers. The U.S. intelligence community should provide the intelligence analysts to work alongside military foreign area officers. Likewise, the Department of State should provide state and regional studies experts as well as expertise in diplomacy. As a result, the Nuclear and Cooperative Threat Reduction Branch will be ajoint and interagency organization consisting of military and civilian government employees with the ability to incorporate contractors where appropriate. It should remain within the Department of Defense for the same reasons that led president Reagan to place it there in 1987: its world wide infrastructure to support implementation and its ability to organize, train and lead inspection teams under often difficult and adverse circumstances. Further, the Department of Defense's reputation as the world leader in treaty verification activities stems from its extensive experience with the Soviet Union and its successor states.

Finally, as a consequence of its competence in performing its core missions, the nuclear branch must also have the ability to augment or parallel international inspectorates (such as the 
International Atomic Energy Agency or United Nations Monitoring, Verification, and Inspection Commission) where necessary to satisfy U.S. interests. The branch will possess the ability to implement verification activities across all three classes of on-site inspection regimes. It will be able to support international arrangements and implement a variety of instruments, bilateral and multilateral, treaty and confidence building. In sum, the events of 11 September have led the Bush Administration to review its strategy for combating terrorism and weapons of mass destruction. The Department of Defense' has a leading role beginning with defeating the threat at the source, before materials find their way into the hands of terrorists and states intent on harming the United States or her allies. To accomplish this task, the services must provide quality personnel with the requisite background and performance to implement on-site inspections in adversarial, traditional, and cooperative inspection regimes to accomplish U.S. security objectives globally.

WORD COUNT $=10,825$ 


\section{ENDNOTES}

${ }^{1}$ George W. Bush, "National Security Strategy Report," www.whitehouse.gov/nsc /nssall.html, 17 September, 2002, 2.

2 John R. Bolton, "Beyond the Axis of Evil: Additional Threats from Weapons of Mass Destruction," Heritage Lecture Series, Heritage Foundation, 6 May 2002, available from http://heritage.org/library/lecture/hl743.html, accessed on 8 November 2002, 4.

${ }^{3}$ Nuclear Threat Reduction Campaign's Agenda to Reduce the Threat of Nuclear Terrorism available from http://www.nuclearthreatreduction.org; accessed on 5 November 2002.

${ }^{4}$ Ibid.

${ }^{5}$ Ibid. 31.

${ }^{6}$ Ashton B. Carter, "Throw the Net Worldwide," The Washington Post, 12 June 2002, sec A,

${ }^{7}$ Nuclear Threat Reduction Campaign Agenda.

${ }^{8}$ Dick Lugar, "Speech: Lugar Envisions U.S.-Russian Front Against Terrorism and Weapons Proliferation," Nuclear Threat Initiative Moscow Conference, available from http://lugar.senate.gov/nunnlugar.htm, accessed on 1 January 2002, 4.

${ }^{9}$ NTRC Campaign Agenda.

${ }^{10}$ Ashton Carter, "Arms Control and Nuclear Terrorism: A Global Coalition Against Catastrophic Terrorism," Testimony before the Senate Armed Services Committee, 1 August 2002, available from http://justice.policy.net/ntrc/studies/ accessed 1 January 2003.

${ }^{11}$ Bolton, "Beyond the Axis of Evil," 1.

${ }^{12}$ Ibid, 3.

${ }^{13}$ Ibid, 3.

${ }^{14}$ Korean Peninsula Energy Development Organization News Release, "KEDO Executive Board Meeting Concludes," 14 November 2002, available from http://www.kedo.org/ accessed on 31 December 2002.

${ }^{15}$ Agreed Framework Between the United States of America and the Democratic People's Republic of Korea, Geneva, 21 October 1994, available from http://www.kedo.org/ accessed on 31 December 2002.

${ }^{16}$ Daniel A. Pinkston, "North Korea Lifts the Freeze on Its Nuclear Program," Center for Nonproliferation Studies, Monterey Institute of International Studies, 16 December 2002, available from http://cns.miis.edu/pubs/ accessed on 31 December 2002.

${ }^{17}$ David R. Sands, "Aid to Iran Seen Diluting U.S. Effort," Washington Times, 10 October 2002, available from http://asp.washtimes.com/ accessed on 24 March 2003. 
${ }^{18}$ Massimo Calbresi, "Iran's Nuclear Threat," Time.Com, 8 Mar 2003, available on www.time.com/time/world/ accessed on 24 Mar 2003.

${ }^{19}$ Carter, "Arms Control," 2.

${ }^{20}$ Bush, "National Security Strategy Report," 2.

${ }^{21}$ State Department Fact Sheet on 1987 INF Missile Treaty, www.usinfo.state.gov, May 16, $2001,2$.

${ }^{22}$ Ibid, 2.

${ }^{23}$ Ibid, 1.

${ }^{24}$ Ibid, 2.

${ }^{25}$ Ibid, 3.

${ }^{26}$ Rose Gottemoeller, "Offense, Defense, and Unilateralism in Strategic Arms Control," www.armscontrol.org/act/2001 09/gottemoellersept01, September 2001, 2.

${ }^{27}$ Daryl Kimball and Kerry Boyd, "Briefing Paper on the Status of Biological Weapons Nonproliferation," www.armscontrol.org/factsheets/bwissuebrief, September 2002, 1.

${ }^{28}$ Ibid, 1.

${ }^{29}$ Ibid, 2.

${ }^{30}$ Leonard Spector and Mark McDonough, Tracking Nuclear Proliferation, Carnegie Endowment for International Peace, 1995, 185.

${ }^{31}$ Spector and McDonough, 171-174.

${ }^{32}$ Frank Blackaby, "Disarmament: The Next Steps," The Review of the CD Agenda, available from http:/www.acronymn.org.uk, January 1996, 1.

${ }^{33}$ WorldAtom Press Release, "Calculating the New Global Nuclear Terrorism Threat," International Atomic Energy Agency,1 November 2001 available from http://www.iaea.org/worldatom/, accessed on 8 November 2002, 1.

${ }^{34}$ Steven Dolley and Paul Leventhal, "Overview of IAEA Inspections in Iraq," Nuclear Control Institute, June 14,2001 www.nci.org/new/iraq-ib.htm, June 14, 2001, 2.

${ }^{35}$ Ibid., 3.

${ }^{36}$ Daryl Kimball and Kerry Boyd, "Briefing Paper on the Status of Biological Weapons Nonproliferation," Arms Control Association, September 2002, available from http://www.armscontrol.org/factsheets/bwissuebrief, 1. 
${ }^{37}$ Preventive Defense Project, International Security Programs, Belfer Center for Science and International Affairs http://bcsia.ksg.harvard.edu/research.cfm?program=ISP\&pb id=11\&gma=19

${ }^{38}$ Sam Nunn, Speech to the World Affairs Council of Washington, D.C., Nuclear Threat Initiative, October 22, 2002, 4., available from www.nti.org.

${ }^{39}$ Ibid., 4.

${ }^{40}$ Preventive Defense Project, International Security Programs, Belfer Center for Science and International Affairs http://bcsia.ksg.harvard.edu/research.cfm?program=ISP\&pb id=11\&gma=19

${ }^{41}$ lbid.

${ }^{42}$ Matthew Bunn, John P. Holdren, and Anthony Weir, Securing Nuclear Weapons and Materials: Seven Steps for Immediate Action, Cambridge: Harvard University, 2002, 62.

${ }^{43}$ Ibid., 62.

${ }^{44}$ Nuclear Threat Reduction Campaign's Agenda to Reduce the Threat of Nuclear Terrorism available from http://www.nuclearthreatreduction.org; accessed on 5 November 2002.

${ }^{45}$ Karl F. Inderfurth, "Statement before the Senate Committee on Foreign Relations," Hearings on the Strategic Offensive Reductions Treaty, 13 September, 2002; available from http://justice.policy.net/ntrc/studies/ accessed 1 January 2003.

${ }^{46}$ Ibid., 2.

${ }^{47}$ Steven Dolley and Paul Leventhal, "Overview of IAEA Nuclear Inspections in Iraq," 3.

${ }^{48}$ Steven Dolley, "Iraq and the Bomb: The Nuclear Threat Continues," $\mathrm{NCl}$ Report 19 February 1998, 13, available from http://www.nci.org/ accessed on 8 November 2002.

${ }^{49}$ Dolley and Leventhal, "Overview of IAEA Nuclear Inspections in Iraq," 3.

${ }^{50}$ Dolley, "Iraq and the Bomb," 13.

${ }^{51}$ lbid., 13.

${ }^{52}$ Ibid., 3.

${ }^{53}$ Inderfurth, "Statement before the Senate Committee on Foreign Relations," 2.

${ }^{54}$ Bush, "National Strategy to Combat Weapons of Mass Destruction," www.whitehouse.gov/, December, 2002, 2.

${ }^{55}$ Ibid., 4.

${ }^{56}$ Ibid., 4. 
${ }^{57}$ Ibid., 4.

${ }^{58}$ Robert Gallucci, "Conversation with Robert Gallucci: U.S. Foreign Policy and Multilateral Negotiations", Conversations with History, February 11, 2002, 4; available from

http://globetrotter.berkeley.edu/people2/Gallucci-con0.html accessed on 20 January 2003.

${ }^{59}$ Carl von Clausewitz, On War, ed. by Michael Howard and Peter Paret (Princeton: Princeton University Press, 1976) 178.

${ }^{60}$ Robert Gallucci, "Reflections on Establishing and Implementing the Post-Gulf War Inspections of Iraq's Weapons of Mass Destruction Programs," Understanding the Lessons of Nuclear Inspections and Monitoring in Iraq: A Ten Year Review, Institute for Science and International Security Conference, 14-15 June 2001, 14; available from www.isisonline.org/publications/iraq/gallucci.html, accessed on 24 January 2003.

61 Joseph Harahan, On-Site Inspections Under the INF Treaty: A History of the On-Site Inspection Agency and INF Implementation, 1988-1991( Washington, D.C.: 1993) 3. 


\section{BIBLIOGRAPHY}

Agreed Framework Between the United States of America and the Democratic People's Republic of Korea, Geneva, 21 October 1994, available from http://www.kedo.org/ accessed on 31 December 2002.

Blackaby, Frank. "Disarmament: The Next Steps," The Review of the CD Agenda, available from http:/www.acronymn.org.uk, January 1996.

Bolton, John R. "Beyond the Axis of Evil: Additional Threats from Weapons of Mass Destruction," Heritage Lecture Series, Heritage Foundation, "National Security Strategy Report," 6 May 2002, available from http://heritage.org/library/lecture/hl743.html, accessed on 8 November 22002.

Bunn, Matthew, Holdren, John and Weir, Anthony. Securing Nuclear Weapons and Materials: Seven Steps for Immediate Action, Cambridge: Harvard University Press, 2002.

Bush, George W. "National Security Strategy Report," www.whitehouse.gov/nsc /nssall.html, September 17, 2002.

Bush, George W. "National Strategy to Combat Weapons of Mass Destruction," www.whitehouse.gov, December, 2002.

Calbresi, Massimo. "Iran's Nuclear Threat," Time.Com, 8 Mar 2003, available on www.time.com/time/world/ accessed on 24 Mar 2003.

Carter, Ashton B. "Arms Control and Nuclear Terrorism: A Global Coalition Against Catastrophic Terrorism," Testimony before the Senate Armed Services Committee, 1 August 2002, available from http://justice.policy.net/ntrc/studies/ accessed 1 January 2003.

Carter, Ashton B. "Throw the Net Worldwide," The Washington Post, 12 June 2002, sec A, 31.

Clausewitz, Carl. On War, ed. by Michael Howard and Peter Paret (Princeton: Princeton University Press, 1976).

Dolley, Steven. "Iraq and the Bomb: The Nuclear Threat Continues," $\mathrm{NCl}$ Report 19 February 1998, available from http://www.nci.org/ accessed on 8 November 2002.

Dolley, and Paul Leventhal, Paul. "Overview of IAEA Nuclear Inspections in Iraq," $\mathrm{NCI}$ Report, 14 June 2001; available from http://www.nci.org/ accessed on 8 November 2002.

Gallucci, Robert. "Conversation with Robert Gallucci: U.S. Foreign Policy and Multilateral Negotiations", Conversations with History, 11 February 2002; available from http://globetrotter.berkeley.edu/people2/Gallucci-con0.html accessed on 20 January 200

Gallucci, Robert. "Reflections on Establishing and Implementing the Post-Gulf War Inspections of Iraq's Weapons of Mass Destruction Programs," Understanding the Lessons of Nuclear Inspections and Monitoring in Iraq: A Ten Year Review, Institute for Science and International Security Conference, 14-15 June 2001; available from www.isisonline.org/publications/iraq/gallucci.html, accessed on 24 January 2003. 
Harahan, Joseph. On-Site Inspection Under the INF Treaty: A History of the On-Site Inspections Agency and INF Implementation, 1988-1991.

Gottemoeller, Rose. "Offense, Defense, and Unilateralism in Strategic Arms Control," www.armscontrol.org/act/2001 09/gottemoellersept01, September 2001.

Inderfurth, Karl F. Statement before the Senate Committee on Foreign Relations Hearings on the Strategic Offensive Reductions Treaty, 13 September, 2002; available from http://justice.policy.net/ntrc/studies/ accessed 1 January 2003.

Kimball, Daryl and Boyd, Kerry. "Briefing Paper on the Status of Biological Weapons Nonproliferation," Arms Control Association, September 2002, available from http://www.armscontrol.org/factsheets/bwissuebrief.

Korean Peninsula Energy Development Organization News Release, "KEDO Executive Board Meeting Concludes," 14 November 2002, available from http://www.kedo.org/ accessed on 31 December 2002.

Lugar, Dick. "Speech: Lugar Envisions U.S.-Russian Front Against Terrorism and Weapons Proliferation," Nuclear Threat Initiative Moscow Conference, available from http://lugar.senate.gov/nunnlugar.htm, accessed on 1 January 2002.

Nuclear Threat Reduction Campaign's Agenda to Reduce the Threat of Nuclear Terrorism available from http://www.nuclearthreatreduction.org; accessed on 5 November 2002.

Nunn, Sam. Speech to the World Affairs Council of Washington, D.C., Nuclear Threat Initiative, October 22, 2002, available from www.nti.org.

Preventive Defense Project, International Security Programs, Belfer Center for Science and International Affairs http://bcsia.ksg.harvard.edu/research.cfm?program=ISP\&pb id=11\&gma=19

Pinkston, Daniel A. "North Korea Lifts the Freeze on Its Nuclear Program," Center for Nonproliferation Studies, Monterey Institute of International Studies, 16 December 2002, available from http://cns.miis.edu/pubs/ accessed on 31 December 2002.

Sands, David R. "Aid to Iran Seen Diluting U.S. Effort," Washington Times, 10 October 2002, available from http://asp.washtimes.com/ accessed on 24 March 2003

Spector, Leonard and McDonough, Mark. Tracking Nuclear Proliferation, Carnegie Endowment for International Peace, 1995.

State Department Fact Sheet on 1987 INF Missile Treaty, www.usinfo.state.gov, May 16, 2001.

WorldAtom Press Release, "Calculating the New Global Nuclear Terrorism Threat," International Atomic Energy Agency, 1 November 2001 available from http://www.iaea.org/worldatom/, accessed on 8 November 2002. 